Idika, E. O. (2021). Students' and Teachers' Factors Hindering Effective Teaching and Learning of Economics In Secondary Schools in the Nsukka Local Government Area of Enugu State

\title{
Students' and Teachers' Factors Hindering Effective Teaching and Learning of Economics in Secondary Schools in the Nsukka Local Government Area of Enugu State
}

\author{
Ezinne Orie Idika* \\ University of Nigeria, Nsukka \\ *Corresponding Author: ezinne.idika@unn.edu.ng \\ Received : 2019-07-07 \\ Rev. Req. : 2019-08-19 \\ Accepted : 2020-01-24
}

10.46303/jcve.2020.4

\begin{abstract}
How to cite this paper: Idika, E. O. (2021). Students' and Teachers' Factors Hindering Effective Teaching and Learning of Economics in Secondary Schools in the Nsukka Local Government Area of Enugu State. Journal of Culture and Values in Education, 4(1), 49-63. https://doi.org/10.46303/jcve.2020.4

This is an Open Access article distributed under the terms of the Creative Commons Attribution 4.0 International license (https://creativecommons.org/licenses/by/4.0/).
\end{abstract}

\section{Abstract}

Students' and teachers' factors that affect effective teaching and learning of economics in secondary schools in the Nsukka Local Government Area of Enugu State, Nigeria, was investigated using 10 out of 31 public schools in the study area. Data was collected using a questionnaire titled "Teachers' \& students' factors hindering effective teaching and learning of Economics in Secondary Schools (TSFETLE)," developed by the researchers and rated on a fourpoint scale. The instrument had 26 items arranged in three clusters. Cluster A elicited information on teacher-related factors hindering effective teaching and learning of economics, Cluster B sought information on student-related factors that hinder effective teaching and learning of economics, and Cluster $\mathrm{C}$ sought information on strategies for effective teaching and learning of economics. The 52 teachers in the 31 government-owned secondary schools and 349 SS2 students of economics in 10 randomly selected secondary schools in the Nsukka Local Government Area of Enugu State were included in the study. Data elicited from three research questions were analyzed descriptively using mean and standard deviation, while t-test was used to compare the teachers' and students' responses. The results of the study showed that teachers' qualifications, teaching methods, and students' attitudes and disposition toward economics are the key factors affecting effective teaching and learning of economics.

Keywords: Teacher factors, Student factors, Effective teaching \& learning of economics 
Idika, E. O. (2021). Students' and Teachers' Factors Hindering Effective Teaching and Learning of Economics In Secondary Schools in the Nsukka Local Government Area of Enugu State

\section{Introduction}

Economics is one of the electives or group of subjects expected to be studied the Senior Secondary School (SSS) level in Nigeria. According to the NERDC (2008), the objectives of the subject in secondary schools are to enlighten students to understand basic economic principles and concepts as well as the tools for sound economic analysis. It enables students to contribute intelligently to discourse on economic reforms and development as they affect or would affect the generality of the citizens, as well as understand the structure and functioning of economic institutions. Economics education is extremely important because it is vital to the future health of our nation's economy. Wion (2008) observed that the purpose of economic education is to create responsible citizens and effective decision-makers. Sadly, our education system is still striving to produce citizens that can discover a way out of our economic state. Examinations have always played a major role in defining and monitoring educational standards because their results are used to measure and assess students' academic achievements. Consequently, students' performance in external examinations such as those conducted by the West African Examination Council (WAEC) and the National Examination Council (NECO) in Economics remain one of the most objective means of evaluating whether or not teaching and learning of economics are effectively done in secondary schools. The key players in achieving these objectives are the teachers, although students also have major roles to play. Teachers are pivotal in the transmission of knowledge, values, and skills in the learning process. Kimani, Kara, and Njagi (2013) noted that if the teacher is ineffective, the students will achieve inadequate progress academically. It is nevertheless the responsibility of students to recognize that they are accountable for their academic success by making choices and taking actions that will lead them toward their educational goals. Hence, this study was designed to investigate students' and teachers' factors hindering effective teaching and learning of economics at secondary school levels. This study is theoretically anchored on Bandura's Social Learning Theory (1977), which posits that people learn from one another via observation, imitation, and modeling. Social learning theory explains human behavior in terms of continuous reciprocal interaction between cognitive, behavioral, and environmental influences. It states that learning is a cognitive process that takes place in a social context (school environment) and can occur purely through observation or direct instruction (teaching), even in the absence of motor reproduction or direct reinforcement. This relates to the present study, which seeks to understand the roles of certain factors that have significant influence on the teaching and learning of economics.

Akinsolu (2010) observed that teachers are vital for student attainment of educational goals and objectives. A teacher is therefore a professional who consciously and deliberately uses a wealth of experience, training, skills, competencies, attitudes, interests, and knowledge of content, with the help of instructional materials and methods/techniques, to impart knowledge to less experienced persons (Mkpa, 2009). Teachers are, therefore, absolutely essential in the entire educational system of any nation and are pivots on which education's wheels revolve. Thus, effective teaching and learning of economics in secondary schools will mainly revolve around the quality and capability of the teachers (Carpenter, 2011). A study by Akinsolu (2010) 
Idika, E. O. (2021). Students' and Teachers' Factors Hindering Effective Teaching and Learning of Economics In Secondary Schools in the Nsukka Local Government Area of Enugu State

on teachers and students' academic performance in Nigerian secondary schools and its implications for planning in a sample of schools drawn from Local Government Areas (LGAs) of Osun State showed that the teachers' qualifications, experience, and teacher-student ratio were positively and significantly related to students' academic performance. This researcher recommended that the finding be used to guide planners about the need for qualified teachers to facilitate effective teaching and learning in secondary schools in Nigeria. Similarly, Ololube (2006) studied influences of academic and professional qualifications on teachers' job effectiveness in Nigerian secondary schools and demonstrated that teachers require professional knowledge and professional teaching skills, as well as a broad base of general knowledge (e.g., morality, service, cultural capital, institutional survey). The researcher recommended that in order to carry out instructional processes effectively, teachers should be trained both academically and professionally.

\section{Statement of Problem}

Economics is a growing subject in secondary education and probably one of the most popular elective subjects offered in secondary schools. Therefore, the importance of effective teaching and learning of economics in the secondary schools cannot be over-emphasized. However, despite the popularity of economics as a secondary school subject, there has been persistent poor achievement by students, as indicated in recent annual Chief Examiner's reports of the West African Senior Certificate Examinations. In addition, most university teachers of economics have expressed the view that prospective university students of economics should not study economics in secondary schools. They contend that it is easier to teach economics to students with no previous knowledge of the subject than to those who were taught economics badly in secondary schools. Therefore, there seem to be several potential problems with the teaching and learning of economics at the secondary school level. The present study is set to investigate the problems hindering effective teaching and learning of economics in secondary schools and to add to already existing knowledge.

The following are the research questions that guided the study:

1. What are the teacher-related factors that hinder effective teaching of economics in senior secondary schools in the Nsukka Local Government Area of Enugu State?

2. What are the student-related factors that hinder effective learning of economics in secondary schools in the Nsukka Local Government Area of Enugu State?

3. What strategies are to be adopted for effective teaching and learning of economics in senior secondary schools in the Nsukka Local Government Area? 
Idika, E. O. (2021). Students' and Teachers' Factors Hindering Effective Teaching and Learning of Economics in Secondary Schools in the Nsukka Local Government Area of Enugu State

\section{Method}

\section{Design of the Study}

A descriptive survey design was used for this study. According to Nworgu (2015), descriptive survey aims at collecting data and describing in a sequential and systematic manner the characteristics of a specific population. This is the design most appropriate for this study.

\section{Sample and Sampling Technique}

A simple random sampling technique was used to select 10 schools out of the 31 public schools in the study area. All 52 Economics teachers in the 31 schools and SS2 students studying economics in the 10 selected schools were included in the study. Students in SS1 classes were excluded from the study because they are new to economics classes and do not have complete sessional results. Likewise, SS3 students were excluded because they were busy with preparations for external examinations.

\section{Data Collection Tool}

A structured questionnaire developed by the researcher, Problems of Teaching and Learning of Economics in Secondary Schools (PTLESS), was used for data collection. The instrument consists of Sections A and B. Section A elicited information on the respondents' demographic data while Section B had three clusters: Cluster A elicited information on teacher-related factors that hinder effective teaching of economics, Cluster B sought information on student-related factors that hinder effective learning of economics, and Cluster $C$ sought information on strategies to be adopted for effective teaching and learning of economics. The clusters were structured on a four-point rating scale of Strongly Agree (SA), weighted four points, Agree (A), weighted three points, Disagree (D), weighted two points, and Strongly Disagree (SD), weighted one point. The instrument was validated by three experts from different specialties in the Faculty of Education, University of Nigeria, Nsukka: two from the Department of Social Science Education (Economics Education) and one from Science Education (Measurement and Evaluation). The experts validated the items, ensuring appropriateness and clarity. Their comments and suggestions were effected and used to produce the final copy of the instrument.

\section{Data Collection}

The researcher visited all 31 public secondary schools in order to reach out to all the economics teachers, administering the questionnaire to the teachers and students in the 10 selected schools. The researcher waited and collected the questionnaires as soon as the respondents filled in their responses to ensure that all questionnaires were collected. 
Idika, E. O. (2021). Students' and Teachers' Factors Hindering Effective Teaching and Learning of Economics in Secondary Schools in the Nsukka Local Government Area of Enugu State

\section{Data Analysis}

The data generated was analyzed using descriptive statistics, and results presented as mean scores and standard deviations were used in answering the research questions that guided the study. The following decision rules were used in ranking the responses by the respondents:

Decision Level (DL)

Strongly Agree (SD)

Agree (A)

Disagree (D)

Strongly Disagree (SD)

\section{Mean Range}

$3.5-4.0$

$2.50-3.49$

$1.50-2.49$

$0.05-1.49$

A mean value of 2.5 was set as the critical mean below which a response is regarded as nonsignificant.

\section{Findings}

The results of this study are presented in Tables 1-4, according to the three research questions that guided the study.

Results presented in Table 1 revealed that items in Cluster A-items 1, 3, 4, 5, 7, 8, 9, 10, 11, 13 , and 14-had means that ranged from 2.60 to 3.43, which are above the criterion mean of 2.5. This means that the majority of the respondents agreed that these teacher-related factors listed in the items hinder effective teaching and learning of economics in secondary schools in Nsukka LGA. On the other hand, items 2, 6, and 12 had mean scores of 2.45, 2.41, and 2.38, which are below the criterion mean of 2.5 set $a b$ initio for the study. This means that the majority of respondents disagreed that those teacher-related factors hinder effective teaching and learning of economics in secondary schools in Nsukka LGA.

Results on the student-related factors that hinder effective teaching and learning of economics in secondary schools in Nsukka LGA (Items 1-20) are presented in Table 2. All the items in the table had mean scores above 2.5, which was the acceptance mean for the study. Items 18, 19, and 20 had very high mean scores of 3.5, 3.22, and 3.50, respectively. This implies that students' lack of interest in economics, negative attitudes about economics, and their non-conversance with figures and calculations are serious problems that hinder effective teaching and learning of economics. 
Idika, E. O. (2021). Students' and Teachers' Factors Hindering Effective Teaching and Learning of Economics In Secondary Schools in the Nsukka Local Government Area of Enugu State

Table 1: Weighted mean response scores on teacher-related factors that hinder effective teaching and learning of economics.

\begin{tabular}{|c|c|c|c|c|}
\hline $\mathrm{S} / \mathrm{N}$ & ITEMS & Mean & $\begin{array}{l}\text { Standard } \\
\text { deviation }\end{array}$ & Decision \\
\hline 1 & $\begin{array}{l}\text { Teachers' inexperience in the choice of appropriate teaching } \\
\text { method }\end{array}$ & 3.23 & 0.64 & A \\
\hline 2 & Unqualified teachers are employed to teach economics & 2.45 & 0.97 & $\mathrm{D}$ \\
\hline 3 & Teachers' lack of knowledge of the subject of matter & 2.75 & 0.71 & A \\
\hline 4 & Nonpayment of teachers' salaries as and when due & 2.60 & 0.81 & A \\
\hline 5 & Poor attendance to classes as stipulated in the time table & 2.95 & 0.83 & A \\
\hline 6 & $\begin{array}{l}\text { Personality of the teacher, e.g., dressing and comportment } \\
\text { during lessons }\end{array}$ & 2.41 & 1.07 & $\mathrm{D}$ \\
\hline 7 & Non-usage of student-centered teaching methods & 3.01 & 0.76 & A \\
\hline 8 & Poor teacher-student interaction in the classroom & 2.97 & 0.88 & A \\
\hline 9 & Improvised instructional materials are provided by the teachers & 2.91 & 0.76 & A \\
\hline 10 & $\begin{array}{l}\text { Lack of competence on the use of available instructional } \\
\text { materials }\end{array}$ & 3.43 & 0.72 & A \\
\hline 11 & Lack of computer literacy & 2.38 & 1.05 & $\mathrm{D}$ \\
\hline 12 & $\begin{array}{l}\text { High student-teacher ratio, which does not encourage } \\
\text { teachers' attention to various ability levels of students }\end{array}$ & 2.84 & 0.80 & A \\
\hline 13 & Unavailability of current and relevant economics textbooks & 3.20 & 0.69 & A \\
\hline 14 & Proximity of the teacher's residence to the school & 3.22 & 0.86 & A \\
\hline
\end{tabular}


Idika, E. O. (2021). Students' and Teachers' Factors Hindering Effective Teaching and Learning of Economics in Secondary Schools in the Nsukka Local Government Area of Enugu State

Table 2: Weighted mean response scores on student-related factors that hinder effective teaching and learning of economics

\begin{tabular}{|c|c|c|c|c|}
\hline $\mathrm{S} / \mathrm{N}$ & ITEMS & Mean & $\begin{array}{l}\text { Standard } \\
\text { deviation }\end{array}$ & Decision \\
\hline 15 & $\begin{array}{l}\text { Students with high mental ability achieve better than those } \\
\text { with low ability in economic lessons }\end{array}$ & 3.04 & 0.85 & $A$ \\
\hline 16 & $\begin{array}{l}\text { Students from high socio-economic backgrounds achieve } \\
\text { better than their counterparts from low socio-economic } \\
\text { backgrounds }\end{array}$ & 3.00 & 0.85 & $A$ \\
\hline 17 & $\begin{array}{l}\text { The age of the learner affects his mastery of abstract } \\
\text { information given in the classroom }\end{array}$ & 2.64 & 1.01 & $A$ \\
\hline 18 & $\begin{array}{l}\text { Lack of student interest in economics hinders effective } \\
\text { learning of the subject }\end{array}$ & 3.35 & 0.85 & $A$ \\
\hline 19 & $\begin{array}{l}\text { Learner's negative attitudes such as truancy affects learning } \\
\text { of economics }\end{array}$ & 3.22 & 0.72 & A \\
\hline 20 & $\begin{array}{l}\text { Students who are not conversant with figures and calculations } \\
\text { find the learning of economics difficult }\end{array}$ & 3.50 & 0.71 & SA \\
\hline
\end{tabular}

Table 3: Weighted mean score of respondents on strategies that should be adopted for effective teaching and learning of economics

\begin{tabular}{|c|c|c|c|c|}
\hline $\mathrm{S} / \mathrm{N}$ & ITEMS & Mean & $\begin{array}{l}\text { Standard } \\
\text { deviation }\end{array}$ & Decision \\
\hline
\end{tabular}

21 Problem-based learning strategies should be used in teaching $\begin{array}{llll}3.04 & 0.70 \quad \mathrm{~A}\end{array}$ economics

22 Student-centered learning methods should be used by the $\begin{array}{llll}3.22 & 0.75 \quad \mathrm{~A}\end{array}$ teachers

23 Field trips and excursions should be in cooperation with the $\begin{array}{llll}2.90 & 0.74 & \mathrm{~A}\end{array}$ teaching of economics 
Idika, E. O. (2021). Students' and Teachers' Factors Hindering Effective Teaching and Learning of Economics In Secondary Schools in the Nsukka Local Government Area of Enugu State

\begin{tabular}{llllll}
\hline 24 & $\begin{array}{l}\text { Formation of school-industry linkage in the teaching of } \\
\text { economics }\end{array}$ & & A \\
25 & $\begin{array}{l}\text { Integrating Information and Communication Technology (ICT) } \\
\text { in the teaching of economics }\end{array}$ & 0.99 & A \\
$26 \quad \begin{array}{l}\text { In-service training such as conferences, workshops, and } \\
\text { seminars to update the teachers' knowledge }\end{array}$ & 0.69 & A \\
\hline
\end{tabular}

All the items in Table 3 had mean scores that ranged from 2.81 to 3.40 and fall within the acceptance mean for the study. This implies that the respondents agreed that all the strategies raised in the table will enhance effective teaching and learning of economics in secondary schools in Nsukka LGA.

Table 4: T-test analysis of the difference between the mean ratings of teachers' and students' responses with regards to effective teaching and learning of economics in Nsukka LGA

\begin{tabular}{|c|c|c|c|c|c|}
\hline Items & Respondents & Mean & $\begin{array}{l}\text { Standard } \\
\text { deviation }\end{array}$ & Decision & $P$ values \\
\hline \multirow[t]{2}{*}{1} & Teachers & 3.50 & 0.53 & A & 0.15 \\
\hline & Students & 3.10 & 0.57 & A & \\
\hline \multirow[t]{2}{*}{2} & Teachers & 3.00 & 0.76 & A & 0.05 \\
\hline & Students & 2.30 & 0.67 & $\mathrm{D}$ & \\
\hline \multirow[t]{2}{*}{3} & Teachers & 3.00 & 0.53 & A & 0.02 \\
\hline & Students & 1.90 & 1.10 & D & \\
\hline \multirow[t]{2}{*}{4} & Teachers & 3.13 & 0.35 & A & 0.10 \\
\hline & Students & 2.50 & 0.53 & A & \\
\hline \multirow[t]{2}{*}{5} & Teachers & 3.13 & 0.64 & $A$ & 0.94 \\
\hline & Students & 3.10 & 0.74 & A & \\
\hline \multirow[t]{2}{*}{6} & Teachers & 2.40 & 0.64 & D & 0.08 \\
\hline & Students & 1.40 & 0.70 & SD & \\
\hline \multirow[t]{2}{*}{7} & Teachers & 2.75 & 0.71 & A & 0.20 \\
\hline & Students & 3.50 & 0.53 & SA & \\
\hline \multirow[t]{2}{*}{8} & Teachers & 3.25 & 0.71 & A & 0.70 \\
\hline & Students & 3.10 & 0.88 & A & \\
\hline \multirow[t]{2}{*}{9} & Teachers & 3.25 & 0.46 & A & 0.38 \\
\hline & Students & 3.00 & 0.67 & A & \\
\hline \multirow[t]{2}{*}{10} & Teachers & 3.75 & 0.46 & SA & 0.40 \\
\hline & Students & 3.50 & 0.71 & SA & \\
\hline
\end{tabular}


Idika, E. O. (2021). Students' and Teachers' Factors Hindering Effective Teaching and Learning of Economics In Secondary Schools in the Nsukka Local Government Area of Enugu State

\begin{tabular}{|c|c|c|c|c|c|}
\hline \multirow[t]{2}{*}{11} & Teachers & 2.38 & 0.74 & $D$ & 0.02 \\
\hline & Students & 3.20 & 0.63 & $A$ & \\
\hline \multirow[t]{2}{*}{12} & Teachers & 1.88 & 0.83 & $D$ & 0.05 \\
\hline & Students & 2.60 & 1.17 & $A$ & \\
\hline \multirow[t]{2}{*}{13} & Teachers & 3.38 & 0.74 & $A$ & 0.80 \\
\hline & Students & 3.30 & 0.48 & $A$ & \\
\hline \multirow[t]{2}{*}{14} & Teachers & 3.63 & 0.74 & SA & 0.26 \\
\hline & Students & 3.20 & 0.79 & $A$ & \\
\hline \multirow[t]{2}{*}{15} & Teachers & 3.25 & 0.46 & $A$ & 0.37 \\
\hline & Students & 2.90 & 0.99 & $A$ & \\
\hline \multirow[t]{2}{*}{16} & Teachers & 3.50 & 0.53 & SA & 0.10 \\
\hline & Students & 3.00 & 0.67 & $A$ & \\
\hline \multirow[t]{2}{*}{17} & Teachers & 3.25 & 0.71 & $A$ & 0.00 \\
\hline & Students & 1.90 & 0.74 & D & \\
\hline \multirow[t]{2}{*}{18} & Teachers & 3.75 & 0.46 & SA & 0.06 \\
\hline & Students & 3.00 & 0.94 & $A$ & \\
\hline \multirow[t]{2}{*}{19} & Teachers & 3.13 & 0.64 & $A$ & 0.63 \\
\hline & Students & 3.30 & 0.82 & $A$ & \\
\hline \multirow[t]{2}{*}{20} & Teachers & 3.88 & 0.35 & SA & 0.22 \\
\hline & Students & 3.60 & 0.52 & SA & \\
\hline \multirow[t]{2}{*}{21} & Teachers & 3.00 & 0.53 & $A$ & 1.00 \\
\hline & Students & 3.00 & 0.67 & $A$ & \\
\hline \multirow[t]{2}{*}{22} & Teachers & 2.63 & 0.52 & $A$ & 0.06 \\
\hline & Students & 3.30 & 0.82 & $A$ & \\
\hline \multirow[t]{2}{*}{23} & Teachers & 3.63 & 0.52 & SA & 0.46 \\
\hline & Students & 3.40 & 0.70 & $A$ & \\
\hline \multirow[t]{2}{*}{24} & Teachers & 3.00 & 0.76 & $A$ & 0.59 \\
\hline & Students & 3.20 & 0.79 & $A$ & \\
\hline \multirow[t]{2}{*}{25} & Teachers & 2.63 & 0.52 & $A$ & 0.20 \\
\hline & Students & 3.10 & 0.88 & $A$ & \\
\hline \multirow[t]{2}{*}{26} & Teachers & 3.25 & 0.89 & $A$ & 0.47 \\
\hline & Students & 3.50 & 0.53 & SA & \\
\hline
\end{tabular}

The t-test analysis as shown in Table 4 showed that the mean scores of the teachers' responses were significantly different $(P \leq 0.05)$ from those of the students in items $2,3,6,11,12$, and 17 . This implies that the teachers and students disagreed notably regarding the items.

\section{Discussion}

Data presented in Table 1 showed that the respondents agree that teacher inexperience in the choice of appropriate teaching methods hinders the effective teaching of economics in the secondary schools. This finding agrees with the study by Wion (2008), who noted that one of the major problems with the teaching of economics is the strategies teachers use to teach the 
Idika, E. O. (2021). Students' and Teachers' Factors Hindering Effective Teaching and Learning of Economics In Secondary Schools in the Nsukka Local Government Area of Enugu State

subject. The ability to choose and use appropriate teaching or instructional methods is a skill that develops with experience. The results also showed that the respondents agree that the usage of non-student-centered learning approaches hinders effective teaching and learning of economics. According to Kini and Podolsky (2016), teacher effectiveness is on average directly proportional to stages of the teaching career, such that the most effective 20-year teachers are significantly more effective than the most effective first-year teachers, and these positive effects reach beyond the experienced teacher's individual classroom to benefit the school as a whole.

In this study and as shown in Table 1, that lack of instructional materials in schools and lack of competence in the use of available instructional materials as well as unavailability of current and relevant economics textbooks also ranked high among teacher-related factors that hinder effective teaching of economics in the secondary schools. The use of instructional materials has been shown by many researchers to improve academic performance of secondary school students in the West Africa School Certificate Examinations (WASCE) (Isola, 2010; Moronfola, 2002). Popoola (1990) also observed that schools with adequate instructional materials performed better than those with inadequate instructional materials. Lack of competence in the use of instructional materials is probably a function of the teachers' quality and experience. A study by Ibrahim (2011) showed that teachers' qualifications and experience were the major factors affecting the use of instructional materials to influence students' academic performance in Agricultural Science in secondary schools. Olumorin, Yusuf, Ajidagba, and Jekayinfa (2010) observed that instructional materials help teachers to teach conveniently and the learners to learn easily. They asserted that instructional materials have direct contact with all sense organs.

In this study, the participants in general (teachers and students) disagreed that unqualified teachers are employed to teach economics, as seen in Table 1. However, a separate analysis of the teachers' and students' responses, as seen in Table 4, showed that the teachers agreed that unqualified teachers are employed to teach economics, whereas the students disagreed. This discrepancy in the response is due to the fact that the students know little or nothing about their teachers' qualifications and as such are not in the best position to judge, unlike the teachers. Therefore, disregarding the students' responses, the study showed that teacher qualification is a factor that hinders effective teaching and learning of economics. The study also indicated teachers' lack of knowledge of the subject as a factor hindering effective teaching of economics in the secondary schools. It has been observed that teaching and learning depends largely on teachers (Ashimole, 2011). Therefore, no educator can effectively teach the students the skills and content of economics when he or she in fact does not have the requisite knowledge and skills. The lack of qualified economics teachers in secondary schools has been noted by others (Adeyemi, 2010; Yala \& Wanjohi, 2011; Yusuf, 2009) as a major factor affecting academic achievement. Yusuf (2009) observed that social studies teachers whose specialty areas are outside economics are the ones who are saddled with the responsibility of teaching secondary school economics in most schools, and a typical social studies educator on average has only completed four to eight credit hours of economics course work in Nigerian universities. 
Idika, E. O. (2021). Students' and Teachers' Factors Hindering Effective Teaching and Learning of Economics In Secondary Schools in the Nsukka Local Government Area of Enugu State

In such cases, some topics of economics are not well comprehended by the teachers themselves and they struggle with the teaching.

The respondents also agreed that nonpayment of teachers' salaries as and when due contributes to the problems hindering effective teaching (Table 1). It is a dictum that a hungry man is an angry man. When salaries of teachers are either delayed unnecessarily or not paid at all, the teachers most times become disenchanted and uncommitted to their duties. The results in Table 1 also showed that teachers' poor attendance to classes as stipulated in the time table hinders effective teaching. Such teachers find it difficult to cover the scheme of work, and when they do, it is hurriedly done without giving the students enough time to learn. Conversely, the results showed that a teacher's comportment during lessons does not affect the teaching and learning of economics. This implies that teacher quality is the force driving effective teaching and learning. This agrees with Harris and Sass (2011), as it is generally accepted that promoting teacher quality is a key element in improving primary and secondary education in the United States.

On the student-related factors that affect the effective teaching of economics in secondary schools in Nsukka LGA, the respondents strongly agreed that students who are not conversant with figures and calculations find the learning of economics difficult. Some topics in economics require calculation, graphs, and charts, so students who are weak in mathematics tend to struggle with economics. The poor performances in economics examinations could be due to the fact that the majority of students who take the course in Senior Secondary levels are mostly non-science-based students. It is known that non-science students are usually weak in mathematics compared to their science-based counterparts. Therefore, these students who take economics in the secondary schools could be ab initio weak in mathematics, hence their poor performance in economics. The results equally showed that students' lack of interest in economics and negative attitudes such as truancy affect their learning. This agrees with Perkins et al. (2005) that students who come into a class with more favorable attitudes are more likely to achieve high learning gains. These researchers observed that the students who learn more tend to be those who have more positive attitudes about the contents of the studies. Thus, it is reasonable to believe that attitudes and beliefs are a leading factor in learning. The kind of attitude a child has affects his school work and learning in general; if he has a positive attitude about the teacher and the subject, success is inevitable. Students' attitudes toward economics determine the degree to which they pass economics, and negative attitudes toward the subject and teachers will definitely have adverse effects on their academic achievement in the subject.

The participants unanimously agreed that students with high intelligent quotient (IQ) achieve better results in economic lessons than those with low ability. Economics has been argued to involve deduction and abstract reasoning. The findings of this study agree with the findings of Obeamata (1991) that student IQ plays a role in the learning of economics. For this reason, it was contended that economics cannot be taught effectively to pupils before they reach the age of 16, before their IQs are developed (Obeamata, 1991). It is also interesting to note that the teachers' response agreed that the age of the learner affects the mastery of abstract 
Idika, E. O. (2021). Students' and Teachers' Factors Hindering Effective Teaching and Learning of Economics In Secondary Schools in the Nsukka Local Government Area of Enugu State

information given in the classroom (Table 4), whereas the students disagreed. Since teachers are in the best position to give an unbiased assessment of student performance, the teachers' response on this item was accepted.

In this study, both teachers and students agreed that students from high socio-economic backgrounds achieve better than their counterparts from low socio-economic backgrounds. This finding is believed to be due to the ability of students from high socio-economic backgrounds to afford relevant economics textbooks and access technology-based learning such as the internet. Simkins (1999) suggested that incorporating technology into the classroom, even with traditional teaching methods, can enhance learning for students with a variety of learning styles, and at the same time make economic content more relevant, interesting, and fun for teachers and students. The internet is a rich source of economic news, data, and information that can make economics relevant and understandable for students in ways that lectures and textbooks alone cannot.

Data presented in Table 3 revealed the mean scores of the participants' responses on the strategies that should be adopted for effective teaching and learning of economics. In the result, both the teachers' and students' responses were in agreement that the following teaching strategies should be adopted: problem-based learning strategies, student-centered teaching methods, field trips, integration of Information and Communication Technology (ICT), and formation of school-industry linkages in the teaching of economics. Many researchers have looked at the different teaching strategies that are implemented in the economics classroom. It is obvious that every student has a particular learning style from which he or she benefits most; therefore, one specific teaching strategy should not be the sole means of presenting the information to the students in the classroom. Rather, teachers should utilize a variety of teaching methods. This allows the students to be actively involved in several different ways without boring them with the same repetitive routine as well as focusing on every student's learning style. The results equally revealed that in-service training such as conferences, workshops, and seminars should be held from time to time to update the teachers' knowledge on the subject. Yusuf (2009) observed the lack of specific conferences or workshops for economics teachers as a major problem hindering effective teaching of economics, and further noted that the Ministries of Education in the country have not thought it necessary to organize or sponsor refresher courses, workshops, or conferences for secondary school teachers of economics. He therefore recommended that the various state Ministries of Education should sponsor or organize conferences, workshops, and refresher courses for secondary school teachers of economics as they have done for other secondary school subjects such as languages, history, and sciences. A subject taught by virtually all schools and offered in the examination by about 90 percent of all candidates annually should be of special interest not only to principals of secondary schools but also to officers of the ministries. 
Idika, E. O. (2021). Students' and Teachers' Factors Hindering Effective Teaching and Learning of Economics In Secondary Schools in the Nsukka Local Government Area of Enugu State

\section{Conclusions}

This study examined teachers' and students' factors that hinder effective teaching and learning of economics in secondary schools in the Nsukka Local Government Area of Enugu State. Based on the findings of the study, the following conclusions were drawn. An overview of the results of the study showed that teachers' qualifications and adaptability to appropriate teaching methods and students' attitudes and disposition toward economics are the key elements affecting effective teaching and learning of the subject. The availability and use of instructional materials were also identified as important factors, as well as inadequate government interventions and support to teachers' welfare and wellbeing.

\section{Recommendations}

From the findings of the study, the following recommendations were made:

1. The relevant government agencies should endeavor to recruit candidates with at least a degree or diploma in Education Economics or an Economics major to teach economics in secondary schools.

2. The Ministry of Education and other relevant authorities should regularly organize refresher courses such as trainings, seminars, conferences, and workshops for economics teachers to keep them abreast of current and productive student-centered teaching and learning methods.

3. Economics teachers should be encouraged to use relevant instructional materials, current textbooks, and examples.

4. The government should do more to ensure teacher welfare through payment of salaries as and when due, provision of accommodation in the form of housing or allowance, office facilities, introduction of reward systems, etc.

\section{References}

Adeyemi, B. (2010). Teacher related factors as correlates of pupils achievement in social studies in south west Nigeria. Electronic Journal of Research in Educational Psychology, 8(1), 313-332.

Akinsolu, A. O. (2010). Teachers and students' academic performance in Nigerian secondary schools: Implications for planning. Florida Journal of Educational Administration and Policy, 3(3), 86-103.

Ashimole, A. U. (2011). Developing teaching manpower through emerging myths and realities in Nigeria institutions. Proceedings of the 2011 International Conference on Teaching, Learning and Change. International Association for Teaching and Learning (IATEL). 
Idika, E. O. (2021). Students' and Teachers' Factors Hindering Effective Teaching and Learning of Economics In Secondary Schools in the Nsukka Local Government Area of Enugu State

Carpenter, B. W. (2011). Developing turn around leadership: Pragmatic guides and contextually specific lessons from the field. Journal of Education for Students Placed at Risk (JESPAR), 16(4), 292-298.

Harris, D. N., \& Sass, T. R. (2011). Teacher training, teacher quality and student achievement. Journal of Public Economics, 95(7).

Ibrahim, U. K. (2011). Influence of instructional materials on the academic performance of students in agricultural science in secondary schools in Kwara State, Nigeria (M. Ed thesis). Ahmadu Bello University, Zaria.

Isola, O. M. (2010). Effects of standardized and improvised instructional materials students' academic achievements in secondary school physics (M. Ed thesis). University of Ibadan, Nigeria.

Kimani, G. N., Kara, A. M., Njagi, L. W. (2013). Teacher factors influencing students' academic achievement in secondary schools in Nyandarua County, Kenya. International Journal of Education and Research, 1(3), 1-14.

Kini, T., \& Podolsky, A., (2016). Does teaching experience increase teacher effectiveness? A review of the research. Palo Alto, CA: Learning Policy Institute. Retrieved from https://learningpolicyinstitute.org/our-work/publications-resources/does-teachingexperience-increase-teacher-effectiveness-review-research

Mkpa, N. D. (2009). Teaching methods and strategies. In U. M. Ivowi (Ed.), Curriculum theory and practice. Lagos: Curriculum organization of Nigeria.

Moronfola, B. (2002). Effects of instruction resources on the academic achievements of secondary school students in Ilorin Local Government of Kwara State (Unpublished M. Ed research thesis).

NERDC. (2008). Economics for senior secondary school. Nigerian Educational Research and Development Council (NERDC).

Nworgu, B. G. (2014). Educational research: Basic issues and methodology (2 ${ }^{\text {nd }}$ ed.). Nsukka: University Trust Publishers.

Obemeata, J. O. (1991). Effective teaching of Economic in senior secondary school. West African Journal of Education, 1(1) 9-13.

Ololube, N. P. (2006). Teacher education, school effectiveness and improvement: A study of academic and professional qualifications on teachers' job effectiveness in Nigerian secondary schools (PhD thesis). University of Helsinki, Faculty of Behavioral Science. 
Idika, E. O. (2021). Students' and Teachers' Factors Hindering Effective Teaching and Learning of Economics in Secondary Schools in the Nsukka Local Government Area of Enugu State

Olumorin, C. O., Yusuf, A., Ajidagba, U. A., \& Jekayinfa, A. A. (2010). Development of Instructional materials from local resources for art-based courses. Asian Journal of Information Technology, 9(2), 107-110. http://dx.doi.org/10.3923/ajit.2010.107.110

Perkins, K. K., Adams, W. K., Pollock, S. J., Finkelstein, N. D., \& Wieman, C. E. (2005). Correlating student attitudes with student learning using The Colorado Learning Attitudes about Science Survey. 2004 Physics Education Research Conference. Melville, NY: American Institute of Physics.

Popoola, T. A. (1990). An investigation into the relationship between instructional resources and students' academic performance in secondary schools in Abeokuta local government area of Ogun State of Nigeria (Unpublished M. Ed thesis).

Simkins, S. (1999). Promoting active student learning using the world wide web in economics courses. Journal of Economic Education, 30, 278-91.

Wion, W. M. (2008). Teacher perspectives on economic education (MSc thesis). Ohio University.

Yala, P. O., \& Wanjohi, W. C. (2011). Performance determinants of KCSE in mathematics of secondary schools in Nyamaiya Division, Kenya. Asian Social Science, 7(2), 107-112.

Yusuf, A. (2009). Economics education. Ilorin Journal of Education (IJE). Retrieved from http//:www.musero.org.ng/economics_education.pdf. pp 10 